\title{
and \\ DNA Barcoding Study of Representative Thymus Species in Bulgaria
}

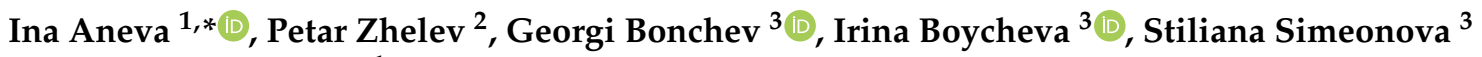 \\ and Denitsa Kancheva ${ }^{1}$ \\ 1 Institute of Biodiversity and Ecosystem Research, Bulgarian Academy of Sciences, 1113 Sofia, Bulgaria; \\ seven_u@abv.bg \\ 2 Department of Dendrology, University of Forestry, 1797 Sofia, Bulgaria; petar.zhelev@ltu.bg \\ 3 Institute of Plant Physiology and Genetics, Bulgarian Academy of Sciences, 1113 Sofia, Bulgaria; \\ georgi.bonchev71@gmail.com (G.B.); irina_boycheva@bio21.bas.bg (I.B.); steli_sim@abv.bg (S.S.) \\ * Correspondence: ina.aneva@abv.bg
}

check for

updates

Citation: Aneva, I.; Zhelev, P.;

Bonchev, G.; Boycheva, I.; Simeonova,

S.; Kancheva, D. DNA Barcoding

Study of Representative Thymus

Species in Bulgaria. Plants 2022, 11,

270. https://doi.org/10.3390/

plants11030270

Academic Editors: Laura

Medina-Puche, Suresh Awale,

Ruth Welti and Juan Antonio García

Alvarez

Received: 25 December 2021

Accepted: 15 January 2022

Published: 20 January 2022

Publisher's Note: MDPI stays neutral with regard to jurisdictional claims in published maps and institutional affiliations.

Copyright: (c) 2022 by the authors. Licensee MDPI, Basel, Switzerland. This article is an open access article distributed under the terms and conditions of the Creative Commons Attribution (CC BY) license (https:// creativecommons.org/licenses/by/ $4.0 /)$.

\begin{abstract}
We present a study on the taxonomy of eleven Thymus species, belonging to two sections and occurring naturally in Bulgaria. Four DNA barcoding markers-matK, rbcL, trnH-psbA and ITS - were applied to discriminate the species and to reveal their phylogenetic relationships. The results showed that rbcL has the lowest discriminating power regarding the studied species, while the other markers yielded results fitting better to the existing taxonomic schemes based on morphological traits. However, even in the case of better performing markers, the results were not straightforwardmorphologically distinct species belonging to different sections were grouped together, and closely related species appeared genetically distinct. The results are typical for taxonomically complex groups, such as the genus Thymus, characterized in Bulgaria with great diversity, high percentage of endemism and still requiring a full and comprehensive taxonomic study. The results are discussed in the light of unresolved taxonomic problems and application of DNA barcoding methods.
\end{abstract}

Keywords: genetic markers; taxonomy; medicinal plants; phylogeny; taxonomically complex groups (TCGs)

\section{Introduction}

Resolving the problems arising when studying taxonomically complex groups (TCGs) requires a combined approach consisting of classical (morphological, anatomical, cytological) and modern (molecular) methods. Representatives of the genus Thymus can be a good example of a complex group encompassing many taxa, some of them with uncertain status, related among each other by hybridization, overlapping phenotypic variation and other attributes of the reticulate evolution, making the task of taxonomists more difficult [1].

The complex systematics of the genus Thymus has been outlined in many studies attempting to resolve the puzzle or a part of it [2-6]. Most of the challenges still stand today, and in many cases, the application of modern molecular methods did not provide a clear solution to taxonomic problems [1,7].

Currently, the number of species of the genus Thymus in Bulgaria is 21 [8-11], and the species list slightly differs from the one in the Euro+Med PlantBase (https://ww2 .bgbm.org/EuroPlusMed/; last accessed 23 December 2021). In terms of species diversity, Bulgaria is among the richest countries in Europe (see also [12], for review). The genus Thymus is subdivided in two subgenera: Coridothymus (Reichenb. f.) Borbás and Thymus [2]. All Bulgarian species belong to the nominate subgenus.

Due to the importance of Thymus species as medicinal and aromatic plants and because of the conservation value of many species, they always provoked a substantial interest and have been subjected to diverse studies. 
The last comprehensive study on the systematics of genus Thymus in Bulgaria was published more than 30 years ago [8], and practically no other taxonomic studies have been performed afterwards, with the exception of some floristic notes [12] and few studies on the essential oil composition [13,14]. Recently, Sostarić et al. [15] studied the genetic diversity and relationships among seven species of section Serpyllum (Miller) Bentham from Serbia. Apart from the taxonomic studies, essential oils and some other bioactive compounds of the species have provoked substantial interest [16-20].

Genetic diversity, evolution and phylogeny of Thymus species have received considerable attention [21-23], with application of newly developed methods. DNA barcoding is one of the modern methods applied successfully to the taxonomy of various groups of living organisms [24-27]. It is often pointed out that in the plant application of barcoding markers, distinguishing among the species is more difficult and not as straightforward as in animals and other organismic groups. The application of barcoding to TCGs in plants experiences some marked difficulties. The success of choosing an appropriate marker that could differentiate between closely related and morphologically similar species depends on many factors, among them polyploidy, the degree of relatedness of taxa of interest, gene flow and hybridization, dispersal ability and other life-history traits (see [25]). Several large-scale phylogenetic studies were performed at a higher than species level and revealed the phylogeny of the genera and tribes within Lamiaceae [28-30]. Genus Thymus was found to be paraphytletic to Argantoniella and Saccocalyx in both nuclear and plastid markers and to Origanum in a plastid marker only [28] and was placed within a clade together with Thymbra, Origanum, Satureja and Micromeria [30]. DNA barcoding has been successfully applied for identifying different species in commercial samples of herbs [31] and for the identification of different Lamiaceae species [32]. However, its application to infrageneric Thymus taxonomy did not allow definite conclusions [1,28,33,34]. Evidently, there are many unresolved problems related to the application of DNA barcoding to TCGs, but the approach is promising and will surely be improved further $[26,27,35]$. Therefore, it is worthy of applying this class of markers to a TCG, whose representatives were studied to a lesser extent.

The objective of the present study was to apply DNA barcoding markers to a representative set of the Bulgarian species of the genus Thymus in order to reveal the relationships among the species in the taxonomic scheme of the genus and to test the effectiveness of the markers for the study of Thymus taxonomy.

\section{Results and Discussion}

\subsection{Efficiency of PCR Amplification and Sequencing}

The success rates for PCR amplification and sequence efficiency were measured for all DNA barcodes obtained using the respective primers (Table 1). In the genus Thymus, primers used for different barcodes showed $100 \%$ amplification and sequencing efficiency among the 15 tested samples. One sample did not amplify, and one sample failed to be sequenced for ITS primers. Alignment length was $760 \mathrm{bp}$ for matK, $530 \mathrm{bp}$ for rbcL, 350 for trnH-psbA and 619 for ITS.

Table 1. Efficiency of PCR amplification and sequencing for Thymus accessions for four DNA barcode regions.

\begin{tabular}{ccccc}
\hline Barcode Region & N (Samples Tested) & $\begin{array}{c}\text { Alignment } \\
\text { Length (bp) }\end{array}$ & $\begin{array}{c}\text { Percentage of } \\
\text { Amplification Efficiency }\end{array}$ & $\begin{array}{c}\text { Percentage of Sequencing Efficiency } \\
\text { (from Amplified Barcodes) }\end{array}$ \\
\hline matK & 14 & 760 & 100 & 100 \\
\hline rbcL & 14 & 530 & 100 & 100 \\
\hline trnH-psbA & 14 & 350 & 100 & 100 \\
\hline ITS & 14 & 619 & 93.4 & 93.4 \\
\hline
\end{tabular}




\subsection{Genetic Diversity of Thymus Species and Accessions}

Table 2 represents the parameters of genetic diversity of the studied DNA barcode regions. The total number of sites varied between 351 (trnH-psbA) to 761 (matK) and up to 1290 when combinations of different barcodes were considered. However, in all cases, more than $90 \%$ of the total number of sites were constant. The number of variable sites varied from 2 to 16 per region and increased to 29 in the combinations of two regions. The number of parsimony-informative sites was of similar magnitude and varied from 2 to 13 .

Table 2. Statistical parameters of genetic diversity calculated in MEGA X.

\begin{tabular}{ccccccc}
\hline DNA Barcode Region & Ns & C & V & Pi & S & Average Pairwise Distance/SE \\
\hline rbcL & 529 & 527 & 2 & 2 & 0 & $0.00127 / 0.00009$ \\
\hline trnH-psbA & 351 & 333 & 16 & 10 & 6 & $0.13205 / 0.00371$ \\
\hline matK & 761 & 748 & 13 & 3 & 10 & $0.00342 / 0.00171$ \\
\hline ITS & 618 & 604 & 14 & 2 & 12 & $0.00464 / 0.00144$ \\
\hline rbcL+matK & 1290 & 1275 & 15 & 5 & 10 & $0.00230 / 0.00066$ \\
\hline rbcL+trnH-psbA & 880 & 860 & 18 & 12 & 6 & $0.00577 / 0.00147$ \\
\hline matK+trnH-psbA & 1112 & 1081 & 29 & 13 & 16 & $0.00748 / 0.00176$ \\
\hline
\end{tabular}

Legend: Ns-total number of sites; C-number of constant sites; V-number of variable sites; Pi-number of parsimony informative sites; S—singleton sites. Estimates of Average Evolutionary Divergence over all Sequence Pairs from the number of base substitutions per site are shown. The standard error estimate(s) were obtained by a bootstrap procedure (1000 replicates). Analyses were conducted using the Tamura-Nei model (see Material and methods). The rate variation among sites was modeled with a gamma distribution (shape parameter $=1$ ). All ambiguous positions were removed for each sequence pair (pairwise deletion option).

We used the software package Geneious to construct a phylogenetic tree to infer genetic distances and the taxonomic relationship between Thymus accessions. A test of different genetic distance models (see Material and Methods) available in the package was performed under the clustering method UPGMA (unweighted pair group method with averages). Among the three models, Jukes-Cantor and Tamura-Nei models displayed highly comparable patterns of clustering of Thymus accessions for all analyzed DNA barcode regions and thus were both considered relevant for use (Supplement-Figures S1 and S2). For further analyses, we used the Jukes-Cantor model, and the constructed phylogenetic trees for different analyzed DNA barcode regions are presented in Figure 1.

The level of genetic discrimination of Thymus specimens based on genetic distances differed between DNA barcode regions used. The rbcL region showed the lowest level of genetic differentiation, with the species specimens T. stojanovii, T. thracicus and T. pulegioides splitting into a distinct cluster (Figure 1a). The data from the rbcL region reflect the close genetic relationships of these species (Figure 1b). While the three species of this cluster belong to the same section Serpyllum (T. pulegioides to subsection Alternantes and the other two species to subsection Pseudomarginati), the second cluster includes all remaining species, which belong to the two sections (Serpyllum and Hyphodromi). The sections were specified based entirely on morphological characters, and some differences between the classification based on morphology and that based on genetic markers are expected. However, the differences and grouping based on the rbcL barcode region do not show some particular trend. Therefore, we consider this region to have little information value for the taxonomic classification of Thymus. Federici et al. [1] found the same sequence length of rbcL in all species studied, and the overall K2P distance was the lowest of all barcoding markers (0.1\%). 


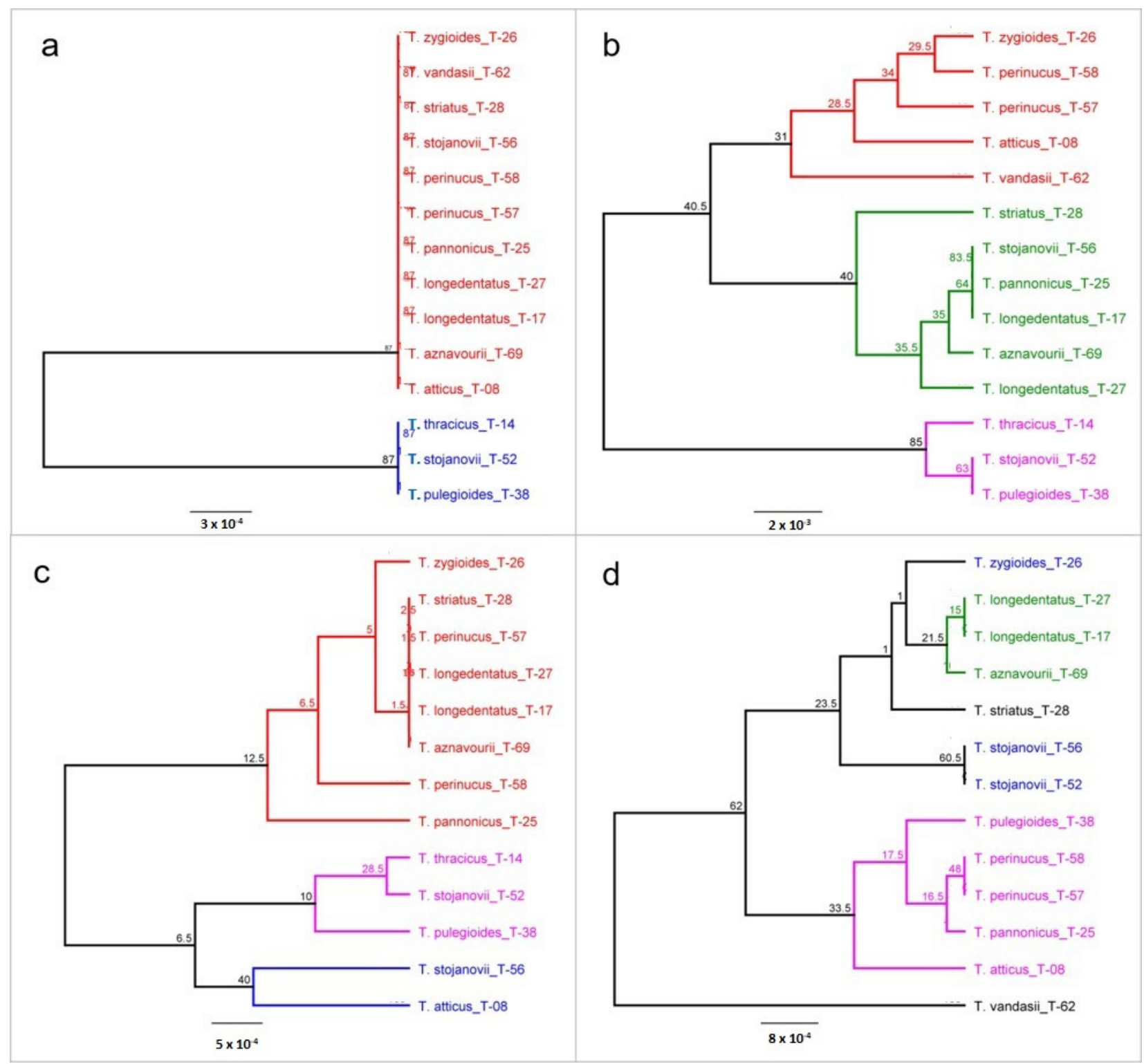

Figure 1. Phylogenetic trees of Thymus taxa constructed based on barcode regions rbcL (a), trnH-psbA (b), matK (c) and ITS (d). The trees were constructed using the Geneious software with the genetic distance model Jukes-Cantor, the unweighted pair group method with averages UPGMA clustering method and the resampling method bootstrap with 200 replicates. Bootstrap values $>50 \%$ are shown along the branches.

The other region (trnH-psbA) showed the highest level of genetic divergence (Figure 1c). Three main groups were formed-two small and a bigger one. The first small group consisted of three species belonging to section Hyphodromi, and the second one combined species of section Serpyllum-similarly to rbcL tree topology. The larger group consisted of three species of section Serpyllum and two of section Hyphodromi. One species-T. vandasii-had a somewhat distinct position.

No particular trend could be observed in the third DNA barcode region matK. Several micro-clusters were formed combining species belonging to different sections, and different accessions of the same species were grouped in different clusters.

The fourth DNA barcode region-ITS-yielded a construction consisting of three clusters and one species distant from the others (Figure 1d). Again, like in the trnH-psbA region, this species was $T$. vandasii. The clusters combined species belonging to different 
sections-for example, the first small cluster consisted of T. zygioides (sect. Hyphodromi) and two accessions of T. stojanovii (sect. Serpyllum). However, it can be noted that here, different accessions of the same species clustered together, contrary to the other barcode regions.

The success of DNA barcoding in distinguishing taxa at the species level in plants depends on many factors [25]. It differs among the different groups and is usually lower in the TCGs, such as genus Thymus.

It has been reported in many studies that DNA barcoding leads to $90 \%$ success in species identification and differentiation [36-38]. However, there were also reports of lower success, especially in the TCGs. For example, [7] obtained about $60 \%$ success in species identification and delimitation in sedges (Carex spp.).

It is known that the combination of DNA barcode markers can improve the resolution of taxonomic and evolutionary studies. Therefore, here, we made an attempt to find out whether a combination of DNA barcode markers that have shown little information value can improve the taxonomic classification of the studied taxa. Phylogenetic trees based on the combination of plastid markers are shown in Figure 2.
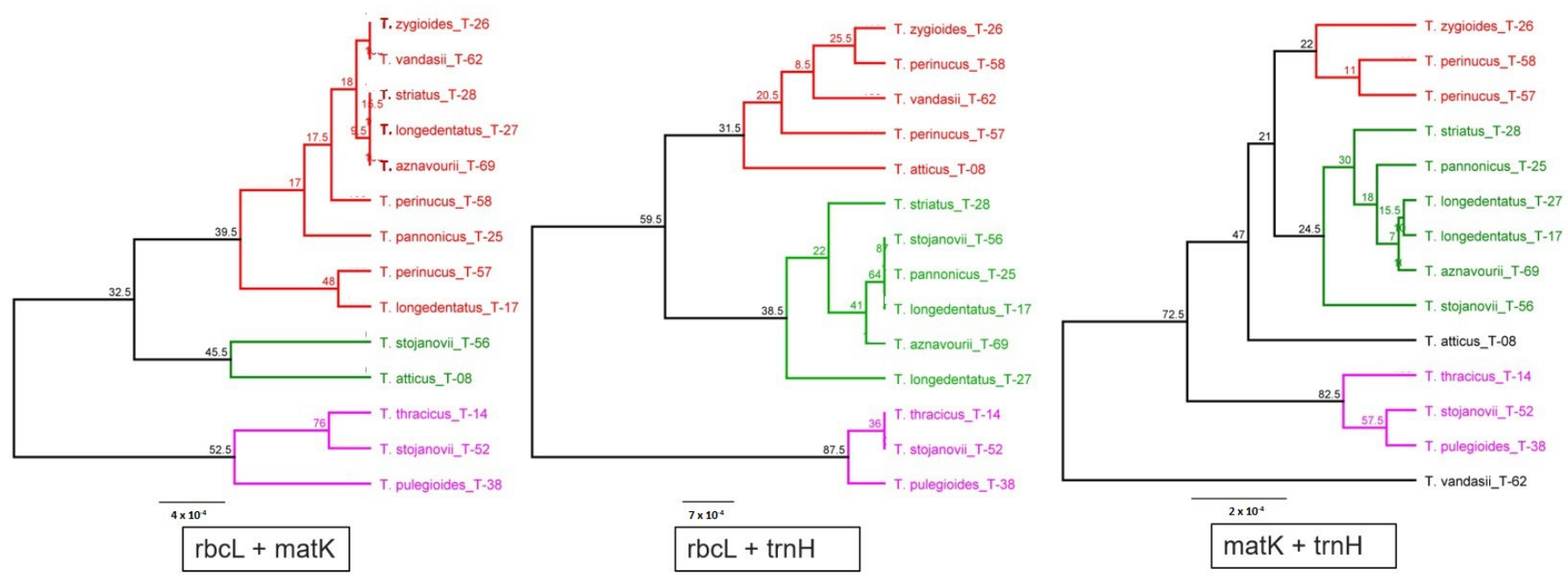

Figure 2. Consensus phylogenetic trees of Thymus taxa constructed based on a combination of plastid DNA barcode markers. The trees were constructed using the Geneious software with the genetic distance model Jukes-Cantor, the clustering method UPGMA and the resampling method bootstrap with 200 replicates. Bootstrap values $>50 \%$ are shown along the branches.

Overall, based on data from the four DNA barcode regions, we can conclude about the presence of pronounced genetic diversity within the genus Thymus. The analyzed rbcL and matK regions alone cannot be used for relevant taxonomic differentiation of Thymus species and accessions. The most effective in distinguishing species and grouping closely related taxa of Thymus together was the ITS region. It was also the most informative region for other TCGs, such as the family Meliaceae [39] and a large set of medicinal plants [38]. It was reported by [39] species belonging to the same TCGs often have identical sequences of cytoplasmic DNA barcoding regions which greatly reduces the discrimination power of these markers. It is often recommended to use two-loci and/or multilocus combinations for obtaining better results $[35,40]$. However, in many studies using multulocus combination of DNA barcoding, markers did not substantially improve the resolution and identification power $[39,41]$.

Phylogenetic trees constructed with combining of DNA barcoding markers yielded similar grouping, like in the case of individual DNA barcodes (Figure 2), and repeating most of the peculiarities established by using individual DNA barcodes. It is difficult to evaluate whether the grouping of different markers provides better results or not.

Taxonomic assignment of Thymus specimens through Basic Local Alignment Search Tool (BLAST) analyses [42] against publicly available accessions in NCBI did not return 
reliable results, probably because the publicly available sequences in the databases represent mostly well-known and studied species with a large distribution, and, to a lesser extent, species from insufficiently studied regions (at least by using molecular markers), such as the Balkans and Bulgaria in particular. Therefore, the most similar to Bulgarian species were ones with a remote distribution, such as T. japonicus (H. Hara) Kitag., T. mongolicus (Ronniger) Ronniger (rbcL barcoding region) and for the ITS region, T. quinquecostatus Celak. and T. serpillum L. (results not shown). Evidently, much more information and richer databases are necessary for reliable application of the BLAST analysis to the Bulgarian Thymus species.

As discussed by [1], often in TCGs, the fragmented populations of the species with reduced or lacking gene flow and long-term evolution in isolation result in spatial structures with morphological and genetic divergence without a strong correspondence among each other. This makes distinguishing taxa very difficult without clearly determined taxonomic boundaries. Plant taxonomy is a complex issue, and speciation processes could be extremely variable, especially in TCGs [43-45].

We consider the present study as a first step toward an updated and taxonomically sound classification of the Bulgarian species of the genus Thymus. Including the remaining indigenous species and such that are not occurring naturally in the country but are important as key species with well-known and established taxonomic positions could facilitate the process of obtaining a proper and reliable classification.

\section{Material and Methods}

\subsection{Plant Material}

Fourteen samples were included in the study, representing eleven species. Five species belong to the section Hyphodromi (A. Kerner) Halácsy and six species to the section Serpillum (Miller) Bentham. The sample set represents all sections of the genus found in Bulgaria. Thymus longedentatus, T. perinicus and T. stojanovii were represented by two samples, while the other species were represented by only one sample (Table 3). The taxonomic system of the genus used in the present study is generally the same accepted in [3] and in Euro+Med PlantBase (https:/ / ww2.bgbm.org/EuroPlusMed/; last accessed 23 December 2021), with slight modifications by [8]. The differences due to the modifications concern only a few taxa: for example, in [8], T. degenii H. Braun is treated as part of T. sibthorpii Benth.; T. kosteleckyanus Opiz as part of T. pannonicus All.; T. odoratissimus Mill. as a synonym of T. glabrescens Willd. However, none of the taxa differing in their taxonomic status between [3] and [8] were included in the present study.

\subsection{DNA Extraction, PCR Amplification and Sequencing}

Leaves dried in silica gel ( $\sim 30 \mathrm{mg})$ were ground to powder by a Mixer Mill MM 40 (Retsch GmbH, Haan, Germany). Genomic DNA was extracted by using an Invisorb ${ }^{\circledR}$ Spin Plant Mini Kit (Invitek Molecular GmbH, Berlin, Germany). DNA concentration and purity was measured by a NandropTM Lite Spectrophotometer (Thermo Fisher Scientific, Waltham, MA, USA). The genetic diversity of samples was evaluated based on sequences of universal barcodes for plants psbA-trnH, matK, rbcL and ITS. The sequence of used primers (synthesized by Microsynth) and PCR conditions that varied among primers are shown in Table 4. PCR amplification was performed in $20 \mu \mathrm{L}$ reaction mixtures containing approximately $30 \mathrm{ng}$ of genomic DNA, 1 x PCR buffer, $\mathrm{MgCl}_{2}$ (2.0 mM for ITS and matK, $2.5 \mathrm{mM}$ for rbcL and trnH-psbA), $0.2 \mathrm{mM}$ of each dNTP, $0.2 \mu \mathrm{M}$ of each primer and $1.0 \mathrm{U}$ Taq DNA Polymerase (Solis BioDyne, Tartu, Estonia). The quality of PCR products was checked on $1 \%$ agarose gel containing GoodViewTM staining dye. Successful amplicon products were sequenced in both directions by Microsynth (Göttingen, Germany) using the same primers used for PCR amplification. 
Table 3. List of the studied specimens with details of their geographic locations.

\begin{tabular}{|c|c|c|}
\hline Species & Sample Code & Geographic Coordinates Altitude \\
\hline \multicolumn{3}{|l|}{ Section Hyphodromi (A. Kerner) Halácsy } \\
\hline \multicolumn{3}{|l|}{ Subsection Subbracteati (Klokov) Jalas } \\
\hline Thymus atticus Čelak. & T08 & $\begin{array}{c}41^{\circ} 25^{\prime} 46^{\prime \prime} \mathrm{N} 23^{\circ} 42^{\prime} 42^{\prime \prime} \mathrm{E} \\
760 \mathrm{~m}\end{array}$ \\
\hline \multirow{2}{*}{ Thymus perinicus (Velen.) Jalas } & T57 & $41^{\circ} 46^{\prime} 13^{\prime \prime} \mathrm{N} 23^{\circ} 24^{\prime} 28^{\prime \prime} \mathrm{E}$ \\
\hline & $\mathrm{T} 58$ & $2450 \mathrm{~m}$ \\
\hline Thymus striatus Vahl. & $\mathrm{T} 28$ & $\begin{array}{c}41^{\circ} 57^{\prime} 52^{\prime \prime} \mathrm{N} 22^{\circ} 56^{\prime} 10^{\prime \prime} \mathrm{E} \\
900 \mathrm{~m}\end{array}$ \\
\hline \multicolumn{3}{|l|}{ Subsection Serpyllastrum Huguet del Villar } \\
\hline Thymus aznavourii Velen. & T69 & $\begin{array}{c}41^{\circ} 50^{\prime} 04^{\prime \prime} \mathrm{N} 26^{\circ} 28^{\prime} 55^{\prime \prime} \mathrm{E} \\
120 \mathrm{~m}\end{array}$ \\
\hline Thymus zygioides Griseb. & $\mathrm{T} 26$ & $\begin{array}{c}41^{\circ} 39^{\prime} 07^{\prime \prime} \mathrm{N} 25^{\circ} 50^{\prime} 39^{\prime \prime} \mathrm{E} \\
300 \mathrm{~m}\end{array}$ \\
\hline \multicolumn{3}{|l|}{ Section Serpyllum (Miller) Bentham } \\
\hline \multicolumn{3}{|l|}{ Subsection Isolepides (Borbás) Halácsy } \\
\hline \multirow{2}{*}{ Thymus longedentatus (Deg. et Urum.) Ronniger } & T17 & $\begin{array}{c}42^{\circ} 03^{\prime} 24^{\prime \prime} \mathrm{N} 24^{\circ} 26^{\prime} 17^{\prime \prime} \mathrm{E} \\
300 \mathrm{~m}\end{array}$ \\
\hline & $\mathrm{T} 27$ & $\begin{array}{c}41^{\circ} 40^{\prime} 30^{\prime \prime} \mathrm{N} 25^{\circ} 49^{\prime} 57^{\prime \prime} \mathrm{E} \\
480 \mathrm{~m}\end{array}$ \\
\hline Thymus pannonicus All. & $\mathrm{T} 25$ & $\begin{array}{c}41^{\circ} 39^{\prime} 06^{\prime \prime} \mathrm{N} 25^{\circ} 50^{\prime} 39^{\prime \prime} \mathrm{E} \\
300 \mathrm{~m}\end{array}$ \\
\hline \multicolumn{3}{|l|}{ Subsection Alternantes Klokov } \\
\hline Thymus pulegioides L. & T38 & $\begin{array}{c}41^{\circ} 47^{\prime} 07^{\prime \prime} \mathrm{N} 23^{\circ} 27^{\prime} 40^{\prime \prime} \mathrm{E} \\
1500 \mathrm{~m}\end{array}$ \\
\hline \multicolumn{3}{|l|}{ Subsection Pseudomarginati (Braun ex Borbás) Jalas } \\
\hline \multirow{2}{*}{ Thymus stojanovii Deg. } & T52 & $\begin{array}{c}41^{\circ} 24^{\prime} 37^{\prime \prime} \mathrm{N} 23^{\circ} 38^{\prime} 57^{\prime \prime} \mathrm{E} \\
1600 \mathrm{~m}\end{array}$ \\
\hline & T56 & $\begin{array}{c}41^{\circ} 33^{\prime} 04^{\prime \prime} \mathrm{N} 24^{\circ} 25^{\prime} 46^{\prime \prime} \mathrm{E} \\
1300 \mathrm{~m}\end{array}$ \\
\hline Thymus thracicus Velen. & $\mathrm{T} 14$ & $\begin{array}{c}41^{\circ} 46^{\prime} 14^{\prime \prime} \mathrm{N} 23^{\circ} 24^{\prime} 48^{\prime \prime} \mathrm{E} \\
2200 \mathrm{~m}\end{array}$ \\
\hline Thymus vandasii Velen. & T62 & $\begin{array}{c}42^{\circ} 12^{\prime} 18^{\prime \prime} \mathrm{N} 23^{\circ} 19^{\prime} 20^{\prime \prime} \mathrm{E} \\
2200 \mathrm{~m}\end{array}$ \\
\hline
\end{tabular}

\subsection{Sequence Alignment and Data Analysis}

Candidate DNA barcodes sequences for each barcode region were edited and aligned in the software packages Geneious (Geneious Prime 2022.0.1) or MEGA-X [46], and consensus sequences were subjected to further analyses. The phylogenetic trees were constructed using the Geneious software testing genetic distance models provided by the software package-the Jukes-Cantor model [47], Hasegawa-Kishino-Yano (HKY) model [48] and Tamura-Nei model [49]. The statistical parameters of genetic diversity (total number of sites, number of variable sites, number of parsimony informative sites singleton sites) were calculated for each DNA barcode marker and some of their combinations in the MEGA-X software package. 
Table 4. Oligonucleotide primers used and PCR conditions.

\begin{tabular}{|c|c|c|c|}
\hline Barcode Region & Primers & $\begin{array}{c}\text { Primer Sequences } \\
\qquad 5^{\prime}-3^{\prime}\end{array}$ & PCR Conditions \\
\hline \multirow{3}{*}{ matK } & MatK-RKIM-f & ACCCAGTCCATCTGGAAATCTTGGTTC & \multirow{3}{*}{$\begin{array}{c}95^{\circ} \mathrm{C} 5 \mathrm{~min} \\
95^{\circ} \mathrm{C} 30 \mathrm{~s}, \\
51^{\circ} \mathrm{C} 50 \mathrm{~s} \\
72^{\circ} \mathrm{C} 1.4 \mathrm{~min}, 35 \mathrm{cycles} \\
72^{\circ} \mathrm{C} 7 \mathrm{~min}\end{array}$} \\
\hline & & & \\
\hline & MatK-3FKIM-r & CGTACAGTACTTTTGTGTTTACGAG & \\
\hline \multirow{3}{*}{ rbcL } & rbcLa-F & ATGTCACCACAAACAGAGACTAAAGC & \multirow{3}{*}{$\begin{array}{c}94^{\circ} \mathrm{C} 4 \mathrm{~min} \\
94{ }^{\circ} \mathrm{C} 30 \mathrm{~s} \\
55^{\circ} \mathrm{C} 30 \mathrm{~s} \\
72{ }^{\circ} \mathrm{C} 1 \mathrm{~min}, 35 \mathrm{cycles} \\
72^{\circ} \mathrm{C} 10 \mathrm{~min}\end{array}$} \\
\hline & & & \\
\hline & rbcLajf634R & GAAACGGTCTCTCCAACGCAT & \\
\hline \multirow{3}{*}{$\operatorname{trnH}-\mathrm{psbA}$} & psbA-trnH & CGCGCATGGTGGATTCACAATCC & \multirow{3}{*}{$\begin{array}{c}94{ }^{\circ} \mathrm{C} 4 \mathrm{~min} \\
94{ }^{\circ} \mathrm{C} 30 \mathrm{~s}, \\
55^{\circ} \mathrm{C} 30 \mathrm{~s}, \\
72{ }^{\circ} \mathrm{C} 1 \mathrm{~min}, 35 \text { cycles } \\
72{ }^{\circ} \mathrm{C} 7 \mathrm{~min}\end{array}$} \\
\hline & & & \\
\hline & psbA-3F & GTTATGCATGAACGTAATGCTC & \\
\hline \multirow{3}{*}{ ITS } & ITS_F1 & CCTTATCATTTAGAGGAAGGAG & \multirow{3}{*}{$\begin{array}{c}94{ }^{\circ} \mathrm{C} 5 \mathrm{~min} \\
94{ }^{\circ} \mathrm{C} 30 \mathrm{~s}, \\
50{ }^{\circ} \mathrm{C} 30 \mathrm{~s}, \\
72{ }^{\circ} \mathrm{C} 1 \mathrm{~min}, 35 \text { cycles } \\
72{ }^{\circ} \mathrm{C} 5 \mathrm{~min}\end{array}$} \\
\hline & & & \\
\hline & ITS 4 & TCCTCCGCTTATTGATATGC & \\
\hline
\end{tabular}

\section{Conclusions}

Low bootstrap support testifies to the unreliability of the majority of groups identified on phylogenetic trees and casts doubt on the possibility of using the studied markers to study phylogenetic relationships in a taxonomically complex group, such as the genus Thymus. A weak trend in pooling samples of the same species indicates the low value of the studied markers for barcoding and suggests the need to look for other markers. Future approaches to the study of Thymus taxonomy and phylogeny should be more complex, including a set of molecular, morphological and other phenotypic markers. Additionally, population genetic studies could provide a reliable picture of the distribution of genetic diversity and the degree of differentiation and could help delineate the real distinct populations and, possibly, the natural entities at the species level, as suggested by [1].

Supplementary Materials: The following supporting information can be downloaded at: https: //www.mdpi.com/article/10.3390/plants11030270/s1.

Author Contributions: Conceptualization, I.A. and P.Z.; methodology, I.A., P.Z. and G.B.; Investigation, I.A., P.Z., G.B., I.B., S.S. and D.K.; data processing, G.B.; writing-original draft preparation, I.A. and P.Z.; writing-review and editing, I.A., P.Z. and G.B.; project administration, I.A.; funding acquisition, I.A. All authors have read and agreed to the published version of the manuscript.

Funding: The funding was provided by the BULGARIAN NATIONAL SCIENCE FUND, Project $\mathrm{DN}-16 / 3$

Institutional Review Board Statement: Not applicable.

Informed Consent Statement: Not applicable.

Data Availability Statement: Data are available from authors on request.

Acknowledgments: The authors thank the financial support provided by the BULGARIAN NATIONAL SCIENCE FUND, Project DN-16/3 and the project BULCode D01-271, Ministry of Education and Science of Bulgaria.

Conflicts of Interest: The authors declare no conflict of interest. 


\section{References}

1. Federici, S.; Galimberti, A.; Bartolucci, F.; Bruni, I.; De Mattia, F.; Cortis, P.; Labra, M. DNA barcoding to analyse taxonomically complex groups in plants: The case of Thymus (Lamiaceae). Bot. J. Linn. Soc. 2013, 171, 687-699. [CrossRef]

2. Jalas, J. Notes on Thymus L. (Labiatae) in Europe. I. Supraspecific classification and nomenclature. Bot. J. Linn. Soc. 1971, 64, 199-215. [CrossRef]

3. Jalas, J. Thymus. In Flora Europaea; Tutin, T., Heywood, V.H., Burges, N.A., Moore, D.M., Valentine, D.H., Eds.; University Press: Cambridge, UK, 1972; Volume 3, pp. 172-182.

4. Baden, C. Thymus L. In Mountain Flora of Greece; Strid, A., Tan, K., Eds.; Edinburgh University Press: Edinburgh, UK, 1986; pp. 139-165.

5. Morales, R. The history, botany and taxonomy of genus Thymus. In Thyme. The Genus Thymus; Stahl-Biskup, E., Sáez, F., Eds.; Taylor \& Francis: London, UK; New York, NY, USA, 2002; pp. 1-43.

6. Bartolucci, F. Verso una revisione biosistematatica del genere Thymus L. In Italia: Considerazioni Nomenclaturali, Sistematiche e Criticità Tassonomica; Annali di Botanica: Rome, Italy, 2009; Volume 2010, pp. 135-148, Supplemento.

7. Starr, J.R.; Naczi, R.F.C.; Chouinard, B.N. Plant DNA barcodes and species resolution in sedges (Carex, Cyperaceae). Mol. Ecol. Resour. 2009, 9 (Suppl. 1), 151-163. [CrossRef] [PubMed]

8. Markova, M. Thymus L. In Flora of PR Bulgaria; Velchev, V., Ed.; BAS: Sofia, Bulgaria, 1989; Volume 9, pp. 288-332. (In Bulgarian)

9. Pavlova, D.; Kozuharova, E.K.; Dimitrov, D.S. The serpentine flora in the Eastern Rhodopes Mountains (Bulgaria). In Progress in Botanical Research: Proceedings of the 1st Balkan Botanical Congress; Tsekos, I., Moustakas, M., Eds.; Kluwer Acdemic Publishers: Dordrecht, The Netherlands, 1998; pp. 133-136.

10. Stoyanov, S.; Marinov, Y. Thymus jalasianus (Lamiaceae), a new species from the serpentine area of the Eastern Rhodope Mountains, Bulgaria. Ann. Bot. Fenn. 2020, 57, 163-172. [CrossRef]

11. Stoyanov, S.; Marinov, Y. Thymus aznavourii (Lamiaceae): First records for Bulgarian and Greek flora. Compt. Rend. Acad. Bulg. Sci. Sci. Math. Nat. 2021, 74, 352-362. [CrossRef]

12. Aneva, I.; Zhelev, P.; Stoyanov, S.; Marinov, Y.; Georgieva, K. Survey on the distribution, diversity and phytochemistry of genus Thymus in Bulgaria. Ecol. Balk. 2018, 10, 101-110.

13. Aneva, I.; Trendafilova, A.; Nikolova, M.; Todorova, M.; Georgieva, K. Essential oil composition of the Balkan endemic Thymus longedentatus (Degen \& Urum.) Ronniger. BLACPMA 2019, 18, 197-203. [CrossRef]

14. Trendafilova, A.; Todorova, M.; Ivanova, V.; Zhelev, P.; Aneva, I. Essential oil composition of five Thymus species from Bulgaria. Chem. Biodivers. 2021, 18, e2100498. [CrossRef] [PubMed]

15. Sostarić, I.; Liber, Z.; Grdiša, M.; Marin, P.D.; Stevanović, Z.; Satović, Z. Genetic diversity and relationships among species of the genus Thymus L. (section Serpyllum). Flora 2012, 207, 654-661. [CrossRef]

16. Kulevanova, S.; Stoeva, T.; Ristić, M. The essential oil composition of Thymus tosevii and Thymus macedonicus from Bulgaria. Boll. Chim. Farm. 2000, 139, 85-88.

17. Marin, P.D.; Grayer, R.J.; Kite, G.C.; Matevski, V. External leaf flavonoids of Thymus species from Macedonia. Biochem. Syst. Ecol. 2003, 31, 1291-1307. [CrossRef]

18. Damianova, S.; Tasheva, S.; Stoyanova, A.; Damianov, D. Investigation of extracts from Thyme (Thymus vulgaris L.) for application in cosmetics. J. Essent. Oil Bear. Plants 2008, 11, 443-450. [CrossRef]

19. Vidić, D.; Ćavar, S.; Solić, M.E.; Maksimović, M. Volatile constituents of two rare subspecies of Thymus praecox. Nat. Prod. Commun. 2010, 5, 1123-1126. [CrossRef]

20. Željković, S.Ć.; Maksimović, M. Chemical composition and bioactivity of essential oil from Thymus species in Balkan Peninsula. Phytochem. Rev. 2003, 14, 335-352. [CrossRef]

21. Tarayre, M.; Saumitou-Laprade, P.; Cuguenl, J.; Couvet, D.; Thompson, J. The spatial genetic structure of cytoplasmic (cpDNA) and nuclear (allozyme) markers within and among populations of the gynodioecious Thymus vulgaris (Labiatae) in southern France. Am. J. Bot. 1997, 84, 1675-1684. [CrossRef]

22. Thompson, J.D. Population structure and the spatial dynamics of genetic polymorphism in thyme. In Thyme. The Genus Thymus; Stahl-Biskup, E., Sáez, F., Eds.; Taylor \& Francis: London, UK, 2002; pp. 44-74.

23. Soorni, A.; Borna, T.; Alemardan, A.; Chakrabarti, M.; Hunt, A.G.; Bombarely, A. Transcriptome landscape variation in the genus Thymus. Genes 2019, 10, 620. [CrossRef]

24. Hebert, P.D.N.; Cywinska, A.; Ball, S.L.; de Waard, J.R. Biological identifications through DNA barcodes. Proc. R. Soc. Lond. B 2003, 270, 313-321. [CrossRef] [PubMed]

25. Hollingsworth, P.M.; Graham, S.W.; Little, D.P. Choosing and using a plant DNA barcode. PLoS ONE 2011, 6, e19254. [CrossRef] [PubMed]

26. Kress, W.J. Plant DNA barcodes: Applications today and in the future. J. Syst. Evol. 2017, 55, 291-307. [CrossRef]

27. Kress, W.J.; Erickson, D.L. (Eds.) DNA Barcodes: Methods and Protocols; Humana Press, Springer SciencepPublishing Media, LLC: New York, NY, USA, 2012; p. 470.

28. Bräuchler, C.; Meimberg, H.; Heubl, G. Molecular phylogeny of Menthinae (Lamiaceae, Nepetoideae, Mentheae)—Taxonomy, biogeography and conflicts. Mol. Phylogenet. Evol. 2010, 55, 501-523. [CrossRef] [PubMed]

29. Zhao, F.; Chen, Y.-P.; Salmaki, Y.; Drew, B.T.; Wilson, T.C.; Scheen, A.-C.; Celep, F.; Bräuchler, C.; Bendiksby, M.; Wang, Q.; et al An updated tribal classification of Lamiaceae based on plastome phylogenomics. BMC Biol. 2021, 19, 2. [CrossRef] [PubMed] 
30. Drew, B.T.; Sytsma, K.J. Phylogenetics, biogeography, and staminal evolution in the tribe Mentheae (Lamiaceae). Am. J. Bot. 2012, 99, 933-953. [CrossRef]

31. De Mattia, F.; Bruni, I.; Galimberti, A.; Cattaneo, F.; Casiraghi, M.; Labra, M. A comparative study of different DNA barcoding markers for the identification of some members of Lamiaceae. Food Res. Int. 2011, 44, 693-702. [CrossRef]

32. Theodoridis, S.; Stefanaki, A.; Tezcan, M.; Aki, C.; Kokkini, S.; Vlachonasios, K.E. DNA barcoding in native plants of the Labiatae (Lamiaceae) family from Chios Island (Greece) and the adjacent Çesme-Karaburun Peninsula (Turkey). Mol. Ecol. Resour. 2012, 12, 620-633. [CrossRef]

33. Abdolahinia, E.D.; Bashir, N.S.; Hagnazari, A.; Nazemiyeh, H.; Hejazi, M.S. A Comparative phenotypic and ITS based genotypic study in Thyme species (Thymus L. Lamiaceae). Int. J. Plant Res. 2011, 24, 102-113.

34. Sonboli, A.; Mirjalili, M.H.; Bakhtiar, Z.; Jamzad, Z. Molecular authentication of Thymus persicus based on nrDNA ITS sequence data. Iran J. Bot. 2013, 19, 179-185.

35. CBOL Plant Working Group. A DNA barcode for land plants. Proc. Natl. Acad. Sci. USA 2009, 206, 12794-12797. [CrossRef]

36. Lahaye, R.; van der Bank, M.; Bogarin, D.; Warner, J.; Pupulin, F.; Gigot, G.; Maurin, O.; Duthoit, S.; Barraclough, T.G.; Savolainen, V. DNA barcoding the floras of biodiversity hotspots. Proc. Natl. Acad. Sci. USA 2008, 105, 2923-2928. [CrossRef] [PubMed]

37. Newmaster, S.G.; Fazekas, A.J.; Steeves, A.D.; Janovec, J. Testing candidate plant barcode regions in the Myristicaceae. Mol. Ecol. Resour. 2008, 8, 480-490. [CrossRef] [PubMed]

38. Chen, S.; Yao, H.; Han, J.; Liu, C.; Song, J.; Shi, L.; Zhu, Y.; Ma, X.; Gao, T.; Pang, X.; et al. Validation of the ITS2 region as a novel DNA barcode for identifying medicinal plant species. PLOS ONE 2010, 5, e8613. [CrossRef] [PubMed]

39. Muellner, A.M.; Schaefer, H.; Lahaye, R. Evaluation of candidate DNA barcoding loci for economically important timber species of the mahogany family (Meliaceae). Mol. Ecol. Resour. 2011, 11, 450-460. [CrossRef]

40. Kress, W.J.; Erickson, D.L. A two-locus global DNA barcode for land plants: The coding rbcL gene complements the noncoding trnH-psbA spacer region. PLoS ONE 2007, 2, e508. [CrossRef] [PubMed]

41. Hollingsworth, M.L.; Clark, A.A.; Forrest, L.L.; Richardson, J.; Pennington, R.T.; Long, D.G.; Cowan, R.; Chase, M.W.; Gaudeul, M.; Hollingsworth, P.M. Selecting barcoding loci for plants: Evaluation of seven candidate loci with species-level sampling in three divergent groups of land plants. Mol. Ecol. Resour. 2009, 9, 439-457. [CrossRef]

42. Altschul, S.F.; Gish, W.; Miller, W.; Myers, E.W.; Lipman, D.J. Basic local alignment search tool. J. Mol. Biol. 1990, 215, 403-410. [CrossRef]

43. Rieseberg, L.H.; Wendel, J. Plant speciation-Rise of the poor cousins. New Phytol. 2004, 161, 1-21. [CrossRef]

44. Rieseberg, L.H.; Wood, T.E.; Baack, E.J. The nature of plant species. Nature 2006, 440, 524-527. [CrossRef]

45. Ennos, R.A.; French, G.C.; Hollingsworth, P.M. Conserving taxonomic complexity. Trends Ecol. Evol. 2005, 20, 164-168. [CrossRef] [PubMed]

46. Kumar, S.; Stecher, G.; Li, M.; Knyaz, C.; Tamura, K. MEGA X: Molecular Evolutionary Genetics Analysis across computing platforms. Mol. Biol. Evol. 2018, 35, 1547-1549. [CrossRef]

47. Jukes, T.H.; Cantor, C.R. Evolution of protein molecules. In Mammalian Protein Metabolism; Munro, H.N., Ed.; Academic Press: New York, NY, USA, 1969; pp. 21-132. [CrossRef]

48. Hasegawa, M.; Kishino, H.; Yano, T. Dating of the Human-Ape Splitting by a molecular Clock of Mitochondrial DNA. J. Mol. Evol. 1985, 22, 160-174. [CrossRef]

49. Tamura, K.; Nei, M. Estimation of the number of nucleotide substitutions in the control region of mitochondrial DNA in humans and chimpanzees. Mol. Biol. Evol. 1993, 10, 512-526. [CrossRef] 